\title{
Effect of cell line on in vitro metal ion cytotoxicity
}

\author{
John C. Wataha', Carl T. Hanks², Zhilin Sun²
}

${ }^{1}$ Department of Prosthodontics and ${ }^{2}$ Department of Oral Medicine, Pathology and Surgery,
University of Michigan School of Dentistry, Ann Arbor, Michigan, USA

\section{ABSTRACT}

Objectives. The choice of cell line for in vitro biological tests which assess the cytotoxicity of dental materials remains controversial, yet this issue is important because these tests are widely used to rate the biocompatibility of new and existing materials, and many different cell lines are commonly used. The purpose of the current study was to quantify the responses of four cell lines (Balb/c 3T3, L929, ROS 17/2.8 and WI-38) to 14 metal ions which are released from dental materials, and relate these responses to the metabolic activity and population doubling times of these cells.

Methods. Succinic dehydrogenase (SDH) activity was used to monitor metabolic activity and cytotoxic response.

Results. The cell lines responded differently to most metal ions. In general, the Balb/c 3T3 line was the most sensitive, and the WI-38 line was the least sensitive. However, there were many exceptions depending on the metal ion. The passage number of the cells also affected the cytotoxic response. It was concluded that the cytotoxicity of materials which release metal ions will be significantly different depending on which cell line is selected and its passage number.

Significance. Based on the findings that cell lines ranked the toxicities of the metal ions similarly, it seems reasonable to use these types of in vitro tests to rank the cytotoxicities of materials. However, if these types of tests are used to predict in vivo cytotoxicity, care should be taken to choose conditions and cells which are relevant.

\section{INTRODUCTION}

Standardized in vitro biological tests are an important part of the overall biocompatibility assessment of dental materials. The usefulness of these tests depends upon identifying and understanding the many variables which can affect their outcome. Kawahara et al. recognized the importance of these variables as early as 1968, and since then, there have been numerous reports which have documented this problem (for example, Hensten-Pettersen and Helgeland, 1977; Mjör et al., 1977; Wennberg et al., 1983; Wataha et al., 1992b).

One critical variable in in vitro biological tests is the type of cells which are used. The issue of which cell lines are desirable and whether selection of cell line makes a significant dif- ference in the outcome of the tests remains controversial and incompletely studied. In 1981, Hanks et al. reported that $\mathrm{Balb} / \mathrm{c}$ 3T3 mouse fibroblasts, a continuously dividing cell line, were more sensitive to dental cements than human periodontal ligament fibroblasts, a primary cell line with limited ability to divide. In an extensive study, Johnson et al. (1983) exposed 12 continuously dividing cell lines to 20 materials, and compared these results to implantation tests in muscle. Although they showed that different cell lines responded differently to the materials, they used nonparametric measurements to quantify these responses. Thus, quantitative comparisons among cell lines was not possible. Pizzoferrato et al. (1985) used epithelial cells (HeLa, KB, EUE lines), lymphocytes, fibroblasts (VERO line) and mouse peritoneal macrophages to evaluate the cytotoxicity of alumina-titania composites, titanium, stainless steel and copper. They concluded that these cells all reacted differently to these materials, but comparisons among the cell lines were difficult because they used different conditions and types of tests for each cell line. Babich et al. (1986) used two different fish egg cell lines (BF-2 and RTG-2) to measure the cytotoxicity of metal ions which occur as aquatic pollutants under identical cell-culture conditions. The RTG cells were less sensitive to the metal ions in all cases, but these cell lines are uncommon in dental materials biocompatibility testing.

More recently, Berstein et al. (1992) have reported that a continuously dividing lymphoma cell line (MOLT 4) was less sensitive to various dental casting alloys than primary human gingival fibroblasts. This finding was in contrast to Hanks et al. (1981) who found a continuous line more sensitive. Finally, Lehmann et al. (1993) used human primary fibroblasts from the gingiva, periodontal ligament, and pulp and compared the reactions of these cells with $\mathrm{Balb} / \mathrm{c}$ mouse fibroblasts (a continuous cell line). There were significant differences in the sensitivities of the cells, even among the primary lines, although in their abstract, the authors did not report the passage of the cell lines or how the purity of the primary lines was verified.

The specifications which govern the in vitro testing of dental materials advocate the use of specific, continuous cell lines from recognized cell repositories (ADA, 1979; ISO, 1993), although the ISO specification allows other cell lines to be used 
if the same results can be shown. These specifications have not addressed possible differences in the sensitivities of these cell lines to biomaterials. Since previous investigators have reported that the selection of the cell lines influences the toxic response to biomaterials (see previous discussion), there is an urgent need to demonstrate, under identical culture conditions, the differences in sensitivities of these cell lines to dental materials.

The previous studies which have addressed the use of different cell-lines have generally exposed these cells to whole materials, such as a dental alloys, composites, or cements, rather than the components of the materials which are released into the oral cavity. This strategy has limited the ability of these authors to quantify the differences among cell lines, since these materials release several components often at different rates (Wataha et al., 1991a; 1992a). Since the amounts of released components cannot be controlled or even easily quantified, the ability to identify the sensitivity of the different cell lines to a component or quantify that sensitivity is severely limited. Furthermore, these studies have often used different cell-culture media or culture conditions for the different cell lines, which has further complicated the ability to compare the different cell lines.

Thus, in the present study, different cell lines were exposed to metal ions which are known to be released from dental materials. Using these ions, dose-response curves were constructed for each metal ion and cell line, thereby establishing quantitatively the sensitivity of each cell line to the metal ions under identical culture conditions. The sensitivity of each cell line was then related to its population doubling time and metabolic activity, since previous research has indicated that these parameters may influence cellular response to metal ions (Babich et al., 1986; Wataha et al., 1993a).

\section{MATERIALS AND METHODS}

Table 1 lists the metal ions which were used, their sources and the ranges of concentrations which were tested. The metallic salts were purchased at the highest purities available (Aldrich, St. Louis, MO, USA). These metal ions were selected based on previous reports that they are released from dental materials into the oral environment (Covington et al., 1985; Brune, 1986; Nourollahi and Meryon, 1989; Muller et al., 1990; Gerstorfer et al., 1991; Wataha et al., 1991a). The concentration ranges were adjusted so that the lowest concentration did not affect the cells, and the highest concentration caused complete cytotoxicity, based on a previous study using Balb/c 3T3 fibroblasts (Wataha et al., 1991b).

Table 2 lists the cell lines used in the current study and their species, phenotypes and American Type Culture Collection (ATCC) numbers. The Balb/c, L929, and WT-38 cell lines were chosen because they are recommended by either the ISO or ADA specifications. The ROS line is a more specialized continuous cell line, and although not available through the ATCC, is still commonly available (Majeska and Rodan, 1982). Furthermore, all cell lines were capable of growing in the same culture medium.

Cells were cultured in F-12 medium (Gibco, Grand Island, NY, USA) supplemented with 5\% NuSerum (Collaborative Research, Bedford, MA, USA), 125 units $/ \mathrm{mL}$ of penicillin (Gibco), $125 \mu \mathrm{g} / \mathrm{mL}$ of streptomycin (Gibco), $2 \mathrm{mmol} / \mathrm{L}$ of glutamine (Gibco), $1.1 \mathrm{mmol} / \mathrm{L}$ of $\mathrm{CaCl}_{2}$ (Gibco), and $28 \mathrm{mmol} / \mathrm{L}$ of

\begin{tabular}{|c|c|c|c|}
\hline \multicolumn{4}{|c|}{ TABLE 1: METAL ION CONCENTRATIONS AND SOURCES } \\
\hline Metal lon & & $\begin{array}{l}\text { Conc. Range Tested } \\
(\mu \mathrm{mol} / \mathrm{L})^{*}\end{array}$ & Source \\
\hline $\mathrm{Ag}^{4+}$ & & $1 \cdot 40$ & $\mathrm{Ag}_{2} \mathrm{SO}_{4}$ \\
\hline $\mathrm{Al}^{3+}$ & & $40-5600$ & $\mathrm{AlCl}_{3}$ \\
\hline $\mathrm{Au}^{3+}$ & & $0.5-250$ & $\mathrm{HAuCl}_{4} \cdot 3 \mathrm{H}_{2} \mathrm{O}$ \\
\hline $\mathrm{Be}^{2+}$ & & $10-550$ & $\mathrm{BeSO}_{4} \cdot 4 \mathrm{H}_{2} \mathrm{O}$ \\
\hline $\mathrm{Cd}^{2+}$ & & $0.5-9.0$ & $\mathrm{CdCl}_{2}$ \\
\hline $\mathrm{CO}^{2+}$ & & $2-200$ & $\mathrm{CoCl}_{2} \cdot 6 \mathrm{H}_{2} \mathrm{O}$ \\
\hline $\mathrm{Cr}^{3+}$ & & $2-1900$ & $\mathrm{CrCl}_{3} \cdot 6 \mathrm{H}_{2} \mathrm{O}$ \\
\hline $\mathrm{Cu}^{2+}$ & & $2-550$ & $\mathrm{CuCl}_{2} \cdot 2 \mathrm{H}_{2} \mathrm{O}$ \\
\hline $\mathrm{Ga}^{3+}$ & & $1.5-220$ & $\mathrm{Ga}\left(\mathrm{NO}_{3}\right)_{3}^{* *}$ \\
\hline $\mathrm{Ni}^{2+}$ & & $2-510$ & $\mathrm{NiCl}_{2} \cdot 6 \mathrm{H}_{2} \mathrm{O}$ \\
\hline $\mathrm{Pd}^{2+}$ & & $10-940$ & $\mathrm{PdCl}_{2}$ \\
\hline $\mathrm{Ti}^{4+}$ & & $20-1900$ & $\mathrm{TiCl}_{4}^{* *}$ \\
\hline$V^{3+}$ & & $1-40$ & $\mathrm{VCl}_{3}^{* *}$ \\
\hline $\mathrm{Zn}^{2+}$ & & $1.5-60$ & $\mathrm{ZnCl} \cdot 6 \mathrm{H}_{2} \mathrm{O}$ \\
\hline \multicolumn{4}{|c|}{$\begin{array}{l}\text { * Indicates lowest and highest concentrations tested. } \\
\text { Controls consisted of solutions of the sodium salts of the anions. } \\
\text { "* Obtained from atomic absorption standard solution. }\end{array}$} \\
\hline \multicolumn{4}{|c|}{ TABLE 2: CELL LINES, SPECIES, AND PHENOTYPE } \\
\hline Cell line & Species & Phenotype & ATCC \# \\
\hline $\mathrm{Balb} / \mathrm{c} 3 \mathrm{~T} 3$ & Mouse & Fibroblast & CCL 163, clone A31 \\
\hline ROS $17 / 2.8$ & Rat & Osteoblast & none \\
\hline L929 & Mouse & Fibroblast & CCL 1, NCTC clone 929 \\
\hline W1-38 & Human & Fibroblast & $\mathrm{CCL} 75$ \\
\hline
\end{tabular}

HEPES buffer (Gibco). Cells were added to culture wells at 20,000 cells $/ \mathrm{cm}^{2} 24 \mathrm{~h}$ before the addition of the metals. Cell metabolic activity was assessed by succinic dehydrogenase (SDH) activity, which is a measure of the mitochondrial activity of the cells. SDH activity was also chosen to measure the cytotoxic effects because previous studies had shown that it was a good overall estimator of the cytotoxicity (Wataha et al., 1991b). Detailed procedures for these measurements are described elsewhere (Wataha et al., 1991b). The population doubling time of the cells was calculated as described in Freshney (1987) from cell counts in a hemocytometer.

The dose-response curves of the cells to the metal ions were determined by adding eight concentrations (at $n=8$ ) of the metal ions diluted in sterile distilled water (Table 1) to the cells for $24 \mathrm{~h}$, after which the SDH activity of the cells was measured. Control solutions contained the sodium salts of the anions. Addition of the metal ions and control solutions did not cause precipitation or a $\mathrm{pH}$ change of more than 0.05 units in the medium. The SDH activity was plotted $v s$. the metal ion concentration for each ion and cell line. The concentration required to cause a 25 or $50 \%$ depression (TC25 or TC50 concentrations, respectively) in SDH activity was esti- 


\begin{tabular}{|ccc|}
\hline \multicolumn{3}{|c|}{ TABLE 3: POPULATION DOUBLING TIMES OF CELL LINES } \\
\hline Cell line & $\begin{array}{c}\text { ATCC Values* } \\
\text { Population } \\
\text { Doubling Time (h) }\end{array}$ & $\begin{array}{c}\text { Expt. } \\
\text { Population } \\
\text { Doubling Time (h) }\end{array}$ \\
\hline Ballb/c 3T3 & 65 & $20(1)^{* *}$ \\
ROS 17/2.8 & - & $41(4)$ \\
L929 & 53 & $42(2)$ \\
W1-38 & 53 & $50(6)$ \\
\hline * Values were calculated from data in the ATCC catalogue of cell \\
lines and hybridomas, 7th ed., 1992. Values for ROS 17/2.8 cells \\
were not available. \\
** Parentheses indicate three standard errors of the means. \\
\hline
\end{tabular}

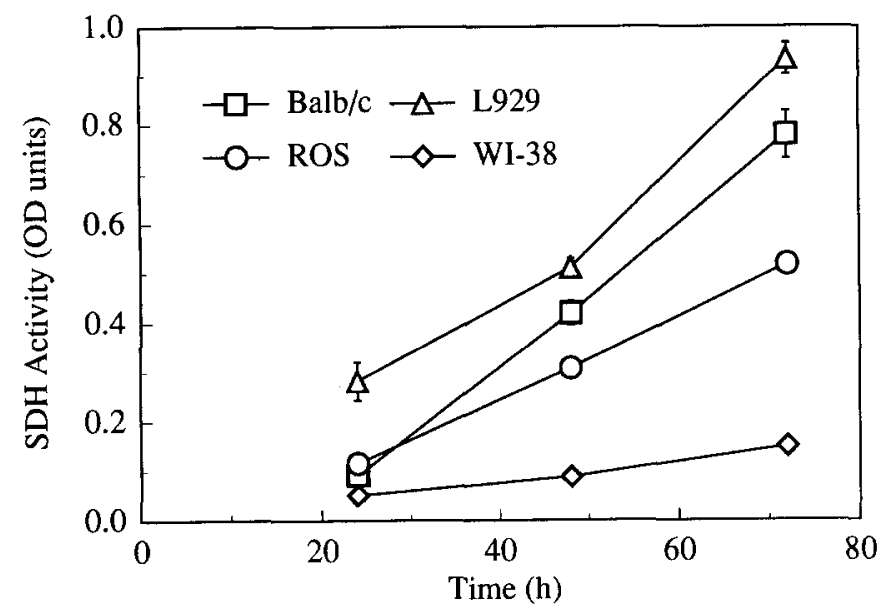

Fig. 1. Succinic dehydrogenase (SDH) activity as a function of time for the four cells lines (Balb/c, L929, ROS, and W/38) in the absence of metal ions. The SDH activity of the cell lines was significantly different throughout the interval of measurement. Error bars (where visible) indicate three standard errors of the means.

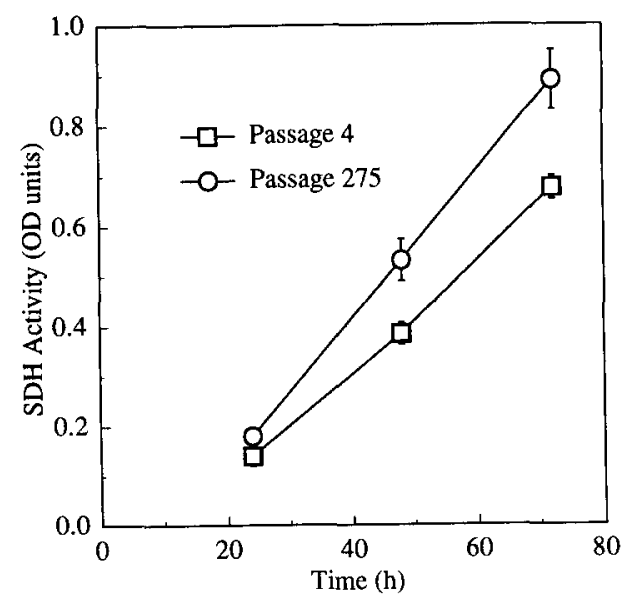

Fig. 2. A comparison of the succinic dehydrogenase (SDH) activity for a Balb/c cell line after dilferent numbers of subcultures in the absence of metal ions. The cell line showed a significantly higher SDH activity after 275 subcultures (Passage 275) than after 4 subcultures (Passage 4). Error bars (where visible) indicate three standard errors of the means.

mated graphically relative to the wells with the control solutions, which were defined as $100 \%$. Errors were also determined graphically from $95 \%$ confidence intervals of the doseresponse line. The TC25 or TC50 values were compared using ANOVA and Tukey intervals $(\mathrm{p}=0.05)$.

\section{RESULTS}

Although the same number of cells were plated initially in all experiments, the cell lines clearly had different SDH activities during the period when the metal ions were added (24-48 h, Fig. 1). The SDH activity showed significant differences at $24 \mathrm{~h}$ which continued through $72 \mathrm{~h}$. In general, the activity of the L929 cells was greatest, followed by the Balb, ROS, and WI-38 cells. The population doubling times for the cell lines are shown in Table 3. To a large extent, these values reflect the growth rates and activities of the cells in Fig. 1, except for the L929 line, which showed a population doubling time similar to the ROS cells, but a metabolic activity closer to the Balb cells.

Fig. 2 shows a comparison of the SDH activities of a Balb cell line after 4 and 275 subcultures. After four subcultures (Passage 4 in Fig. 2), the cells had a lower SDH activity at all time intervals than after 275 subcultures (Passage 275). The increased activity of the latter group was probably a consequence of selection of the most actively dividing cells over the period of the subcultures (approximately 26 months). The difference in activity of the two passage numbers was the basis for comparing the cytotoxic response to the metal ions.

The responses of the cell lines to the metal ions are shown in Table 4. For each ion, the concentration required to cause a 50\% decrease in the SDH activity (TC50) is shown. In cases where the concentration ranges used were insufficient to cause a $50 \%$ decrease, the concentration required to cause a $25 \%$ decrease (TC25) is shown $\left(\mathrm{Al}^{3+}, \mathrm{Ga}^{3+}, \mathrm{Ni}^{2+}\right)$. Low TC50 or TC25 values indicate a more toxic metal ion. Thus in Table 4, the ROS cells were more sensitive to $\mathrm{Ag}^{1+}$ than $\mathrm{L929}$ cells because it took a lower concentration of $\mathrm{Ag}^{1+}$ to reduce the SDH activity $50 \%(10.8 \mu \mathrm{mol} / \mathrm{L})$ for the ROS cells than for the L929 cells $(30.1 \mu \mathrm{mol} / \mathrm{L})$. The WI-38 cells were generally the least sensitive to the metal ions, indicated by the higher TC50 values. Titanium and chromium were exceptions because the Balb cells were less sensitive to titanium, and no cell line was sensitive to the chromium ions. Beyond this trend, there was no cell line which was consistently the most sensitive to all metal ions, although the Balb cells were commonly more sensitive than the other cell lines. Although the TC25 or 50 values for a given metal ion were statistically different when evaluated by different cell lines, they were in the same range. Thus, for example, Cd TC50 values ranged from 0.8 to $9 \mu \mathrm{mol} / \mathrm{L}$, whereas $\mathrm{Au}$ values ranged from 60 to $115 \mu \mathrm{mol} / \mathrm{L}$, and $\mathrm{Cr}$ was consistently greater than $1900 \mu \mathrm{mol} / \mathrm{L}$.

When the data in Table 4 were compared with the population doubling times in Table 3 , there was some indication that shorter doubling times implied increased sensitivity, since the Balb cells, with the shortest doubling time, were often more sensitive to the metal ions than the WI-38 cells, with the longest doubling time. However, beyond this generalization, there were many exceptions, and for the ROS and L929 cells, there was no clear correlation. For the cell activities shown in Fig. 1, the WI-38 cells were the least sensitive and also had the lowest SDH activity. The L929 cells had the highest SDH activity, but were not the most sensitive cell line to the metal ions as often as the Balb cells.

In spite of the lack of an ideal correlation between toxicity and metabolic activity or population doubling time, most of the cell lines ranked the toxicities of the metal ions similarly (Table 5). For an unbiased comparison, Table 5 lists only ele- 


\begin{tabular}{|c|c|c|c|c|c|c|c|}
\hline Cell line & $\mathrm{Ag}^{1+}$ & $\mathrm{Al}^{3+*}$ & $\mathrm{Au}^{3+}$ & $\mathrm{Be}^{2+}$ & $\mathrm{Cd}^{2+}$ & $\mathrm{Co}^{2+}$ & $\mathrm{Cr}^{3+}$ \\
\hline Balb/c 3Т3 & $25.5(2.6)^{\star \star}$ & $3000(250)$ & $60(3)$ & $780(280)$ & $6.6(0.3)$ & $62(14)$ & $>1900$ \\
\hline ROS $17 / 2.8$ & $10.8(0.6)$ & $3100(130)$ & $91(5)$ & $2520(650)$ & $0.8(0.1)$ & $232(33)$ & $>1900$ \\
\hline L929 & $30.1(2.2)$ & $3200(450)$ & $109(4)$ & $880(210)$ & $5.4(0.3)$ & $232(23)$ & $>1900$ \\
\hline \multirow[t]{2}{*}{ WI-38 } & $>38$ & $4000(200)$ & $115(3)$ & $>4500$ & $>9$ & $>225$ & $>1900$ \\
\hline & $\mathrm{Cu}^{2+}$ & $\mathrm{Ga}^{3+*}$ & $\mathrm{Ni}^{2+*}$ & $\mathrm{Pd}^{2+}$ & $\mathrm{Ti}^{4+}$ & $\mathrm{V}^{3+}$ & $\mathrm{Zn}^{2+}$ \\
\hline Balb/c 3Т3 & $235(15)$ & $71(32)$ & $110(25)$ & $190(15)$ & $1050(180)$ & $15.6(1.0)$ & $35.0(2.5)$ \\
\hline ROS $17 / 2.8$ & $172(7)$ & $72(33)$ & $235(25)$ & $290(15)$ & $200 \quad(35)$ & $17(1.7)$ & $50 \quad(5)$ \\
\hline L929 & $135(10)$ & $100(12)$ & $220(48)$ & $280(13)$ & 280 & $>40$ & $33.5(0.7)$ \\
\hline WI-38 & $460(20)$ & $>275$ & $>500$ & $330(60)$ & $760 \quad$ (23) & $25.5(3.5)$ & $59(1.5)$ \\
\hline
\end{tabular}

ments which caused a $50 \%$ depression of SDH activity. Since metal ions most often inhibited the WI-38 cells by less than $50 \%$, these cells were omitted from the Table. The ranking of the toxicities of the ions was remarkably similar. Differences in one or two rank steps among the cell lines was common, but the ranking rarely differed by more than two steps for any element. For example, $\mathrm{Cd}$ andAg ions were consistently among the most toxic elements, Be was among the least toxic, and $\mathrm{Zn}, \mathrm{Au}, \mathrm{Cu}$ ions were generally midrange. Ti was exceptional because it was less toxic to Balb and L929 lines, but was markedly more toxic with the ROS line.

When $\mathrm{Cd}^{2+}$ and $\mathrm{Cu}^{2+}$ were exposed to Balb cells which were subcultured different numbers of times, a significant difference in the SDH activity response was seen (Fig. 3). The cells which were subcultured the most times (Passage 275) and which had the higher SDH activity rates (Fig. 2) were less sensitive to these metal ions than the cells which were subcultured less. Furthermore, low concentrations of each of these metals showed a slight stimulation of SDH activity in the Passage 275 group.

\section{DISCUSSION}

Although the cell lines ranked the metal ions similarly by SDH activity, it was difficult to relate the differences among the cell lines to any single factor which was evaluated, including phenotype or species of the cells (Tables 2 and 4). The results did not completely support the hypothesis that a high metabolic rate or a short population doubling time would increase the sensitivity of the cells to the metal ions. The L929 cells, which generally had the highest metabolic activity, were sometimes the most sensitive to the metal ions, and WI-38 cells, which were the least active, were also the least sensitive in most cases. However, there were many exceptions, and a general statement relating cell activity and toxic response was not possible.

Values for the population doubling times of the cells differed from values published in the ATCC catalogue in some

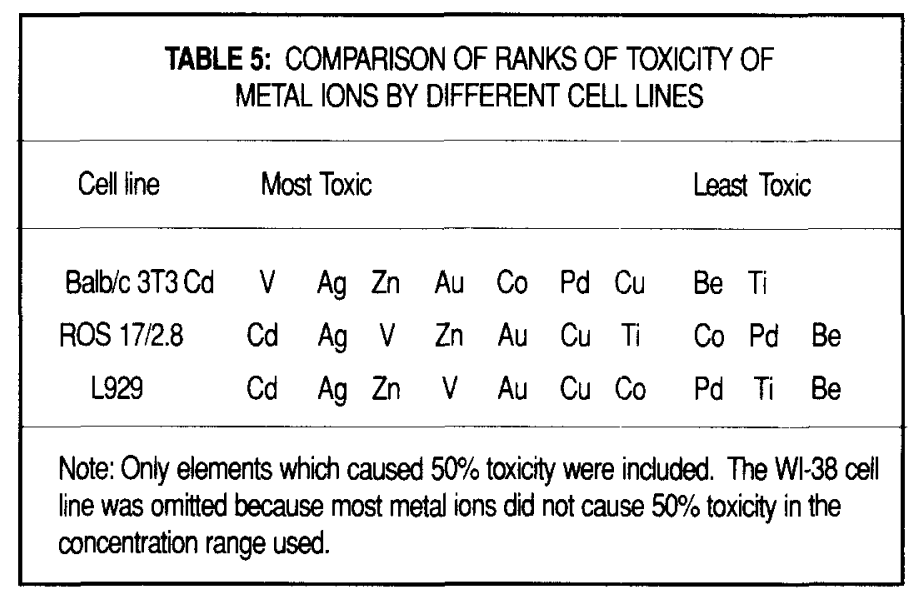

cases (Table 3). The discrepancy was largest for the Balb/c 3T3 cell line. The reasons for the discrepancies are not clear, but changes in the medium and serum composition as well as selection of faster growing cells during repeated subculture are probably responsible.

It was clear that even with a single continuous cell line, the activity of the cell line and its response to metal ions changed as the number of subcultures increased (Figs. 2 and 3). This result was significant because continuous cell lines, which have relatively reproducible growth rates and biological responses (ISO, 1993), are often recommended for standardized tests. Furthermore, these results in Fig. 3 did not adequately explain the cell density effects previously reported (Wataha et al., 1993a). Previously, it was hypothesized that since Balb cells were less sensitive to metal ions when plated at high monolayer densities, the lower metabolic activity of these high density cultures was responsible for the reduced sensitivity. Thus, it was expected that the less active cell line (Passage 4 in Figs. 2 and 3) would be less sensitive to metal ions. However, the data in Fig. 3 tend to refute this hypothesis since Balb cell cultures with higher activities were less sensitive to $\mathrm{Cd}$ and $\mathrm{Cu}$ than cultures with lower activities. 


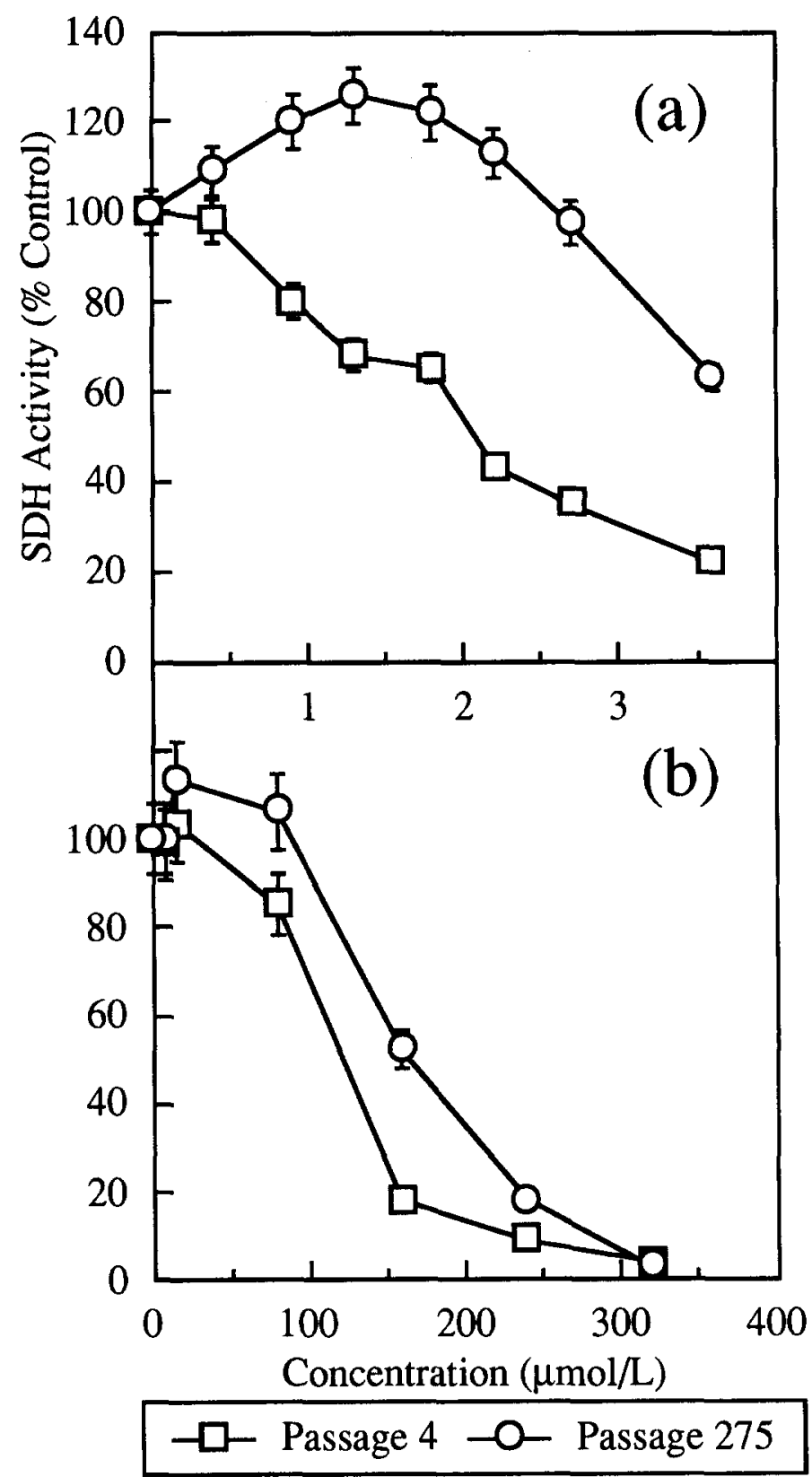

Fig. 3. The response of Balb/c cells in different passage numbers to $\mathrm{Cd}^{2+}(\mathrm{a})$ and $\mathrm{Cu}^{2+}(\mathrm{b})$. Cell response was measured by dehydrogenase (SDH) activity after $24 \mathrm{~h}$ of incubation with the metal ions. Cells in the two different passage numbers responded differently to the metal ions. Error bars (where visible) indicate three standard errors of the means.

The toxicity of the metal ions in the current study for $\mathrm{Balb} / \mathrm{c}$ 3T3 cells were not always in agreement with previous reports (Wataha et al., 1992b). For example, the TC50 value for SDH activity for $\mathrm{Ag}^{1+}$ was previously found to be $5.8 \mu \mathrm{mol} / \mathrm{L}$, whereas the value in the current study was $25.5 \mu \mathrm{mol} / \mathrm{L}$. These discrepancies may be caused by the variables in the experimental procedure including the passage number of the cells and the cell density. This hypothesis was supported by the results of the current study and previous studies (Wataha $e t$ al., 1993a). Althcugh other cells lines were not tested, cell density and passage number could affect their cytotoxic responses as well.

The results of the current study are in agreement with those of previous investigators who have reported that different cell lines respond to biomaterials differently (Johnson et al., 1983; Pizzoferrato et al., 1985; Berstein et al., 1992). However, the results in the current study quantify these differences and permit direct comparisons among cell lines because identical culture conditions were used to test the biomaterials. Interestingly, the ranking of the metal ion cytotoxicity in the current study for $\mathrm{Cd}, \mathrm{Zn}, \mathrm{Cu}$, and $\mathrm{Ni}$ was identical to that reported by Babich et al. (1986) using fish egg cell lines, although the TC50 values for the two studies were significantly different. Finally the results reported by Hanks et al. in 1981 support the current findings that $\mathrm{Balb} / \mathrm{c}$ 3T3 fibroblasts tend to be more sensitive to dental materials than other cell lines.

The lack of a clear pattern in the response of the different cell lines to the metal ions reinforces previous reports that each metal ion affects cells in a specific way (Williams, 1981; Wataha et al., 1991b; 1993b). Thus, the particular toxicity of a metal ion in a given cell line may depend upon more specific metabolic differences than were measured in the current study, such as production of metallothioneins or other specific proteins, and the ways by which the metal ions react with those specific processes.

In summary, it was concluded that the apparent cytotoxicity of materials which release metal ions will be significantly affected by which cell line is selected for the test. Furthermore, such results can change as the cell line is subcultured over many times, despite the use of continuous cell lines from the ATCC registers. However, it seems reasonable to use these types of tests to rank materials based on the findings that cell lines ranked the toxicities of the metal ions similarly. If information beyond simple ranking of toxicities is required, care must be taken to choose the cell line which is most relevant to the in vivo situation of interest since the response of a given cell line is likely to vary considerably.

\section{ACKNOWLEDGMENTS}

We acknowledge the support of our work through the National Institutes of Health (Grant DE09296).

Received January 31, 1994 / Accepted April 24, 1994

Address correspondence and reprint requests to:

John C. Wataha

University of Michigan School of Dentistry

Department of Prosthodontics

$1011 \mathrm{~N}$. UniversityAvenue

Ann Arbor, MI 48109-1078 USA

\section{REFERENCES}

ADA (1979). ADA specification \#41 for recommended standard procedures for biological evaluation of dental materials. J Am Dent Assoc 99:697-698.

Babich H, Shopsis C, Borenfreund $\mathrm{E}$ (1986). In vitro cytotoxicity testing of aquatic pollutants $(\mathrm{Cd}, \mathrm{Cu}, \mathrm{Zn}, \mathrm{Ni})$ using established fish cell lines. Ecotoxicol Environ Safety 11:9199.

Berstein A, Benaur I, Marx R, Geurtsen W (1992). Human cell culture studies with dental metallic materials. Biomaterials 13:98-100.

Brune D (1986). Metal release from dental biomaterials. Biomaterials 7:163-175. 
Covington JS, McBride MA, Slagle WF, Disney AL (1985). Quantitization of nickel and beryllium leakage from base metal casting alloys. J Prosthet Dent 54:127-136.

Freshney R (1987). Culture of Animal Cells. New York: Alan R. Liss.

Gerstorfer JG, Sauer KH, Pässler K (1991). Ion release from $\mathrm{Ni}-\mathrm{Cr}-\mathrm{Mo}$ and $\mathrm{Co}-\mathrm{Cr}-\mathrm{Mo}$ casting alloys. Int $J$ Prosthodont 4:152-158.

Hanks CT, Anderson M, Craig RG (1981). Cytotoxic effects of dental cements on two cell culture systems. J Oral Pathol 10:101-112.

Hensten-Pettersen A, Helgeland K (1977). Evaluation of biologic effects of dental materials using four different cell culture techniques. Scand J Dent Res 85:291-296.

ISO 10993-5(1993). Biological evaluation of medical devicesPart 5: Tests for cytotoxicity: In vitro methods. International Standards Organization, Geneva.

Johnson HJ, Northup SJ, Seagraves PA, Garvin PJ, Wallin $\mathrm{RF}$ (1983). Biocompatibility test procedures for materials evaluation in vitro. I. Comparative test system sensitivity. $J$ Biomed Mater Res 17:571-586.

Kawahara H, Yamagami A, Nakamura M (1968). Biological testing of dental materials by means of tissue culture. Int Dent $J$ 18:443-467.

Lehmann F, Leyhausen G, Geurtsen W (1993). Cytotoxic alterations in different fibroblast cultures caused by matrix monomers. J Dent Res 72:219, Abstr. No. 929.

Majeska RJ, Rodan GA (1982). Alkaline phosphatase inhibition by parathyroid hormone and isoproterenol in a clonal rat osteosarcoma cell line. Possible mediation by cyclicAMP. Calcif Tiss Int 34:59-66.

Mjör IA, Hensten-Pettersen A, Skogedal O (1977). Biologic evaluation of filling materials. A comparison of results using cell culture techniques, implantation tests, and pulp studies. Int Dent J 27:124-129.
Muller AWJ, Maessen FJMJ, Davidson CL (1990). Determination of the corrosion rates of six dental NiCrMo alloys in an artificial saliva by chemical analysis of the medium using ICP-AES. Dent Mater 6:63-68.

Nourollahi M, Meryon SD (1989). The antibacterial properties of four elements released from dental restorative materials. Int Endo $J$ 22:9-16.

Pizzoferrato A, Vespucci A, Ciapetti G, Stea S (1985). Biocompatibility testing of prosthetic implant materials by cell culture. Biomaterials 6:346-351.

Wataha JC, Craig RG, Hanks CT (1991a). The release of elements of dental casting alloys into cell culture medium. $J$ Dent Res 70:1014-1018.

Wataha JC, Hanks CT, Craig RG (1991b). The in vitro effects of metal cations on eukaryotic cell metabolism. J Biomed Mater Res 25:1133-1149.

Wataha JC, Craig RG, Hanks CT (1992a). The effects of cleaning on the kinetics of in vitro metal release from dental casting alloys. J Dent Res 71:1417-1422.

Wataha JC, Hanks CT, Craig RG (1992b). In vitro synergistic, antagonistic, and duration of exposure effects of metal cations on eukaryotic cells. J Biomed Mater Res 26:12971309.

Wataha JC, Hanks CT, Craig RG (1993a). The effect of cell monolayer density on the cytotoxicity of metal ions which are released from dental alloys. Dent Mater 9:172-176.

Wataha JC, Hanks CT, Craig RG (1993b). Uptake of metal cations by fibroblasts in vitro. J Biomed Mater Res 27:227232.

Wennberg A, Mjör IA, Hensten-Pettersen A (1983). Biological evaluation of dental restorative materials: A comparison of different test methods. J Biomed Mater Res 17:23-36.

Williams DF (1981). Toxicology of implanted metals. In: The Fundamental Aspects of Biocompatibility. Boca Raton: CRC Press, Chapter 2. 